J. Lake Sci. (湖泊科学), 2015, 27 (5): 932-940

DOI $10.18307 / 2015.0521$

(c) 2015 by Journal of Lake Sciences

\title{
淮河干流浮游动物群落结构特征
}

\author{
吴 利 $^{1}$, 李源玲 ${ }^{2}$, 陈延松 ${ }^{1}$ \\ $(1$ : 合肥师范学院生命科学学院, 合肥 230061$)$ \\ ( 2 : 安徽病原生物学省级实验室和人兽共患病安徽省重点实验室 (安徽医科大学) ; 安徽医科大学病原生物学教研室, 合 \\ 肥 230022)
}

\begin{abstract}
摘 要: 2011 年 $3 、 6 、 9$ 和 12 月对淮河干流 11 个采样点的浮游动物群落结构进行调查研究, 共检出浮游动物 79 属 206 种, 其中原生动物 27 属 69 种, 占浮游动物总物种数的 $33.5 \%$; 轮虫 35 属 104 种, 占 $50.5 \%$; 枝角类 12 属 27 种, 占 $13.1 \%$; 桡足类 5 属 6 种, 占 $2.9 \%$. 总体上看, 从上游至下游, 浮游动物物种数呈现逐渐减少的趋势. 浮游动物的丰度和生 物量分别为 $3527447 \mathrm{ind}$. $/ \mathrm{L}$ 和 $2452 \mathrm{mg} / \mathrm{L}$, 轮虫和原生动物丰度是淮河干流浮游动物丰度的主体, 轮虫生物量是淮河干 流浮游动物生物量的主体, 浮游动物及各类群丰度和生物量均表现为从上游到中游逐渐增高的趋势, 而从中游到下游呈 现逐渐降低的趋势. 上游浮游动物多样性指数和均匀度指数高于中、下游. 结果表明: 淮河干流上游水质为轻污染, 中、下 游水质为中污染或重污染. 浮游动物群落结构和环境因子的咒余分析表明, 水温、溶解氧和流速是与淮河干流浮游动物 群落结构相关性较强的环境因子
\end{abstract}

关键词: 浮游动物; 群落结构;水质;淮河干流

\section{Characteristics of community structures of zooplankton in the mainstream of Huaihe River}

WU Li ${ }^{1}$, LI Yuanling ${ }^{2} \&$ CHEN Yansong ${ }^{1}$

(1: School of Life Sciences, Hefei Normal University, Hefei 230061, P. R. China)

(2: Anhui Provincial Laboratory of Pathogen Biology, Anhui Key Laboratory of Zoonosis, Department of Microbiology and Parasitology, Anhui Medical University, Hefei 230022, P. R. China)

\begin{abstract}
The zooplankton community structures at 11 sampling sites in the mainstream of Huaihe River were investigated in March, June, September and December of 2011. A total of 206 species belonging to 79 genera were identified. Protozoa has 69 species (33.5\% of the total) of 27 genera; Rotifer has 104 species (50.5\%) of 35 genera; Cladocera has 27 species (13.1\% ) of 12 genera, and Copepoda has 6 species $(2.9 \%)$ of 5 genera. Consequently, the number of species showed a steady decreasing trend from the upper reaches to the lower reaches. The density and biomass of zooplankton were $3527447 \mathrm{ind}$. $/ \mathrm{L}$ and $2452 \mathrm{mg} / \mathrm{L}$, respectively. The abundance of protozoa and rotifer were on predominance, and the biomass of rotifer was on predominance. The middle reaches had the highest abundance and biomass of zooplankton. The Shannon-Wiener index and Pielou evenness index of zooplankton in the upper reaches were higher than those in the middle and the lower reaches. This study showed that the water quality of the upper reaches of Huaihe River was in oligotrophic status, while the middle and lower reaches were in mesotrophic status or eutrophic status. Redundancy analysis showed that temperature, dissolved oxygen and velocity were strongly correlated with the zooplankton community structures.
\end{abstract}

Keywords: Zooplankton; community structures; water quality; the mainstream of Huaihe River

浮游动物是水域生态系统中重要的生物组成部分, 包括原生动物、轮虫、枝角类和桡足类. 浮游动物个 体小、数量多、代谢旺盛, 以浮游植物、细菌、碎屑等为食, 同时它们也是鱼类和其他水生动物的食物, 其动态

* 安徽省自然科学基金项目(1208085QC61)、高等学校省级优秀青年人才基金重点项目(2012SQRL164ZD) 和合肥师范 学院生化与分子生物学特色重点学科项目联合资助. 2014-06-23 收稿;2014-11-28 收修改稿. 吴利 (1981 ), 女,博士,副教授;E-mail:wuli090121@126. com. 
变化影响鱼类和无脊椎动物的种群生物量, 因此其在水域生态系统中发挥着重要作用 ${ }^{[1]}$. 浮游动物多样性 是水域生态系统服务功能的重要指标之一, 其种类组成和现存量的变动能及时准确地反映水域生态环境的 优劣 ${ }^{[2-3]}$.

淮河干流自西向东,经河南省南部、安徽省中部, 在江苏省中部注人洪泽湖, 全长约 $1000 \mathrm{~km}$. 整个淮河 流域总面积约为 $190000 \mathrm{~km}^{2}$, 地处亚热带与温带的过渡区, 为我国主要的粮食产区 ${ }^{[4]}$. 淮河流域干流地区为 典型的人口高密度区, 伴随着近年快速的城市化进程, 人类对该流域生态系统的干扰日趋严重, 大量的工业 废水、城市污水排人河道,使淮河的自然调蓄功能逐渐萎缩, 自然生态环境逐渐恶化, 使得河流功能退化现 象突出,淮河的健康备受关注,因此,对淮河流域水环境状况进行调查研究非常重要. 目前,对淮河流域部分 断面的浮游动物研究较多 ${ }^{[5-8]}$, 而对整个淮河干流浮游动物的研究仅见部分报道 ${ }^{[9]} .2011$ 年本研究对淮河干 流 11 个采样点的浮游动物进行多样性调查, 以期为淮河干流的水环境评价、治理、保护及水资源合理开发 利用提供理论依据.

\section{1 材料与方法}

\section{1 采样时间和采样点设置}

2011 年 3 月 (春季)、6 月(夏季)、9 月(秋季)和 12 月(冬季)对淮河干流进行取样调查,共设置 11 个采 样点, 依次从上游至下游分布 (图 1). 所有采样点均经 GPS 定位.

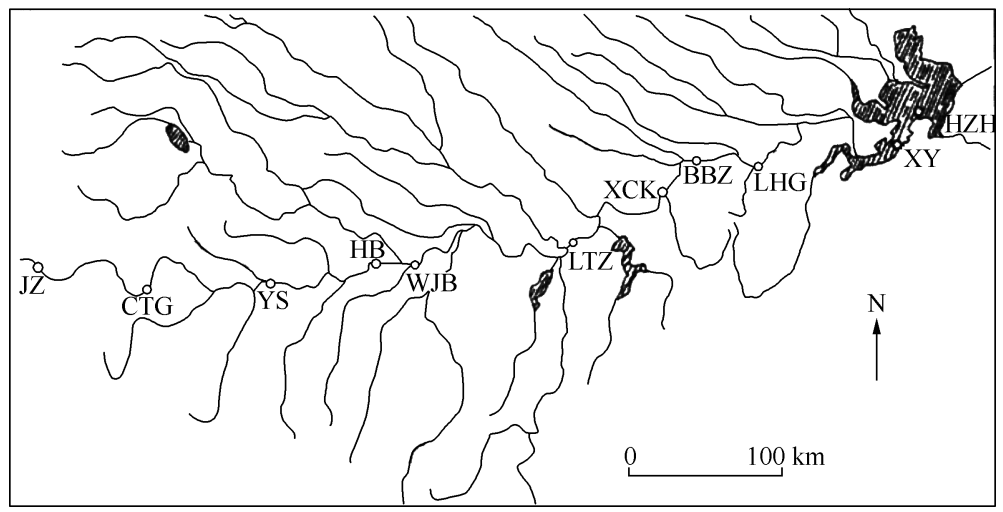

图 1 淮河干流浮游动物采样点分布 (桐柏金庄 $(\mathrm{JZ}) 、$ 长台关大桥 ( CTG)、尹 山( YS)、淮滨 (HB)、王家坝 (WJB)、鲁台子 ( LTZ)、新城口 (XCK)、蚌埠闸 下 $(\mathrm{BBZ}) 、$ 临淮关 $(\mathrm{LHG}) 、$ 盱眙大桥 $(\mathrm{XY})$ 、洪泽湖人口 $(\mathrm{HZH}))$

Fig. 1 Sampling sites of zooplankton in the mainstream of Huaihe River

\section{2 样品的采集与鉴定}

1.2. 1 定性样品 样品以 $25^{\#}$ 浮游生物网 ( 孔径 $64 \mu \mathrm{m}$ ) 在上层水体呈 “ $\infty$ ” 字形捞取 $3 \sim 5 \mathrm{~min}$, 并将滤取的 样品放人样品瓶中,加 $4 \%$ 的甲醛溶液固定. 参照文献 [10-14] 的描述, 在 $100 \sim 1000$ 倍 Zeiss Axioplab 2 imaging 显微镜下鉴定浮游动物种类.

1.2 .2 定量样品 浮游动物定量样品的采集与观察参照文献 [ 15$]$ 的方法, 浮游动物丰度计算公式为:

$$
N=\left(V_{\mathrm{s}} \cdot n\right) /\left(V \cdot V_{\mathrm{a}}\right)
$$

式中, $N$ 为水中浮游动物的总个体数 (ind. $/ \mathrm{L}), V$ 为采样体积 $(\mathrm{L}), V_{\mathrm{s}}$ 为沉淀体积 $(\mathrm{ml}), V_{\mathrm{a}}$ 为计算体积 $(\mathrm{ml}), n$ 为计数所得的个体数.

\section{2 .3 生物量的计算 参照文献 $[3]$ 换算浮游动物生物量.}

\section{3 分析方法}

物种多样性的计算采用 Shannon-Wiener 指数 $\left(H^{\prime}\right)^{[16]}$,其计算公式为: 


$$
H^{\prime}=-\sum_{i=1}^{S}\left(P_{i}\right)\left(\ln P_{i}\right)
$$

物种均匀度指数 $(J)$ 采用 Pielou ${ }^{[17]}$ 的计算公式:

$$
J=\frac{H^{\prime}}{H_{\max }}=\frac{H^{\prime}}{\log _{2} S}
$$

式中, $S$ 为浮游动物种类总数, $P_{i}$ 为第 $i$ 种的个体数与样品中总个数的比值 $\left(N_{i} / N\right)$.

\section{4 理化参数的测定}

理化参数的测定参照丁建华等 ${ }^{[4]}$ 的方法.

\section{5 数据处理}

浮游动物丰度和理化数据进行 $\log _{10}(x+1)$ 转换以使数据呈正态分布, 各季节理化参数差异的判别用 SPSS 13.0 软件进行单因素方差分析 (one-way ANOVA), 并取 $P<0.05$ 作为差异显著性判定标准. 运用去趋 势对应分析 (detrended correspondence analysis, DCA) 和元余分析 (redundancy analysis, RDA) 探讨淮河干流 浮游动物群落物种丰度与环境因子的关系. DCA 和 RDA 在 CANOCO 4. 5 软件中实现.

\section{2 结果与分析}

\section{1 理化参数分析}

淮河干流 4 个季节理化参数详见丁建华等的研究 ${ }^{[4]}$.

\section{2 浮游动物的种类组成}

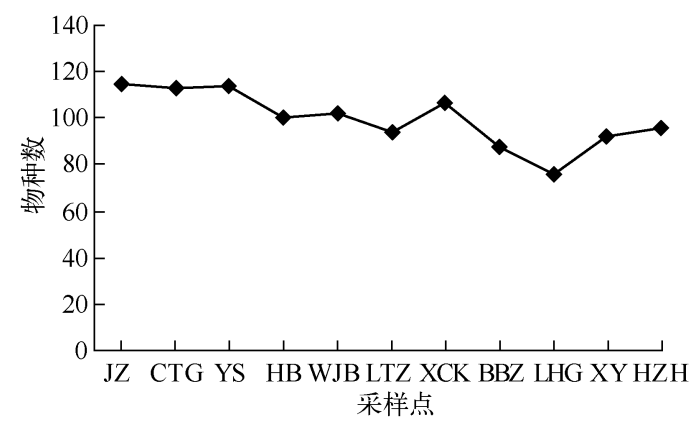

图 2 淮河干流不同采样点浮游动物物种数

Fig. 2 Species number of zooplankton in different sites in the mainstream of Huaihe River

表 1 淮河干流浮游动物及各类群丰度与生物量

Tab. 1 Abundance and biomass of zooplankton and its taxas in the mainstream of Huaihe River

\begin{tabular}{crrrr}
\hline 类群 & $\begin{array}{c}\text { 丰度/ } \\
(\mathrm{ind} . / \mathrm{L})\end{array}$ & $\begin{array}{c}\text { 相对丰度/ } \\
\%\end{array}$ & $\begin{array}{r}\text { 生物量/ } \\
(\mathrm{mg} / \mathrm{L})\end{array}$ & \multicolumn{1}{c}{$\begin{array}{c}\text { 相对生物量/ } \\
\%\end{array}$} \\
\hline 原生动物 & 1706664 & 48.38 & 87 & 3.55 \\
轮虫 & 1740035 & 49.33 & 2048 & 83.51 \\
枝角类 & 3410 & 0.10 & 68 & 2.78 \\
桡足类 & 77338 & 2.19 & 249 & 10.16 \\
\hline
\end{tabular}

4 个季节共鉴定出浮游动物 79 属 206 种, 其中原生动物 27 属 69 种, 占浮游动物总 物种数的 $33.5 \%$; 轮虫 35 属 104 种, 占 $50.5 \%$; 枝角类 12 属 27 种, 占 $13.1 \%$; 桡足 类 5 属 6 种, 占 $2.9 \%$. 总体上看, 淮河干 流浮游动物物种数以小型浮游动物 (原生 动物和轮虫) 为主, 并且从上游至下游, 浮 游动物物种数呈现逐渐减少的趋势 ( 图 2).

\section{3 浮游动物丰度与生物量}

调查期间, 淮河干流所有采样点浮游动 物总丰度为 3527447 ind. $/ \mathrm{L}$, 其中原生动物 的相对丰度为 $48.38 \%$, 轮虫相对丰度为 $49.33 \%$, 枝角类和桡足类所占比例较低, 相 对丰度分别为 $0.10 \%$ 和 $2.19 \%$. 轮虫和原生 动物丰度是淮河干流浮游动物丰度的主体. 浮 游动物生物量为 $2452 \mathrm{mg} / \mathrm{L}$, 其中轮虫的相对 生物量为 $83.51 \%$, 原生动物为 $3.55 \%$, 枝角 类和桡足类分别为 $2.78 \%$ 和 $10.16 \%$. 轮虫生 物量是淮河干流浮游动物生物量的主体 (表 1 ). 浮游动物、原生动物、轮虫、枝角类丰度均 以夏季最高, 桡足类丰度以春季最高 (表 2).

不同采样点浮游动物丰度以鲁台子最 高, 为 $452185 \mathrm{ind}$. /L; 原生动物丰度以临淮关最高, 为 $331736 \mathrm{ind}$. $/ \mathrm{L}$; 轮虫和枝角类丰度以王家坝最高, 分 
别为 281948 和 $946 \mathrm{ind} . / \mathrm{L}$; 桡足类丰度以新 城口最高, 为 $2112 \mathrm{ind} . / \mathrm{L}$, 浮游动物及各类 群丰度均以桐柏金庄最低. 浮游动物、轮虫和 枝角类生物量均以王家坝最高, 分别为 $366.59 、 338.34$ 和 $18.91 \mathrm{mg} / \mathrm{L}$; 原生动物生 物量以临淮关最高, 为 $16.59 \mathrm{mg} / \mathrm{L}$; 桡足类生 物量以新城口最高, 为 $8.10 \mathrm{mg} / \mathrm{L}$, 浮游动物 及各类群生物量均以桐柏金庄最低. 整体看 来,浮游动物及各类群丰度和生物量均表现 为从上游到中游逐渐增高的趋势, 而从中游 到下游呈现逐渐降低的趋势(图 3 ).
表 2 淮河干流浮游动物及各类群丰度的季节变化

Tab. 2 Seasonal variations of the abundance of zooplankton and its taxas in the mainstream of Huaihe River

\begin{tabular}{crrrr}
\hline \multirow{2}{*}{ 类群 } & \multicolumn{4}{c}{ 丰度/ (ind. /L) } \\
\cline { 2 - 5 } & 春季 & 夏季 & 秋季 & 冬季 \\
\hline 原生动物 & 29439 & 82285 & 33039 & 16128 \\
轮虫 & 51006 & 109390 & 12420 & 7808 \\
枝角类 & 24 & 219 & 38 & 14 \\
桡足类 & 5813 & 200 & 93 & 48 \\
浮游动物 & 86282 & 192094 & 45590 & 23998 \\
\hline
\end{tabular}

\section{口浮游动物 口原生动物 曰轮虫口枝角类 $\square$ 桡足类}
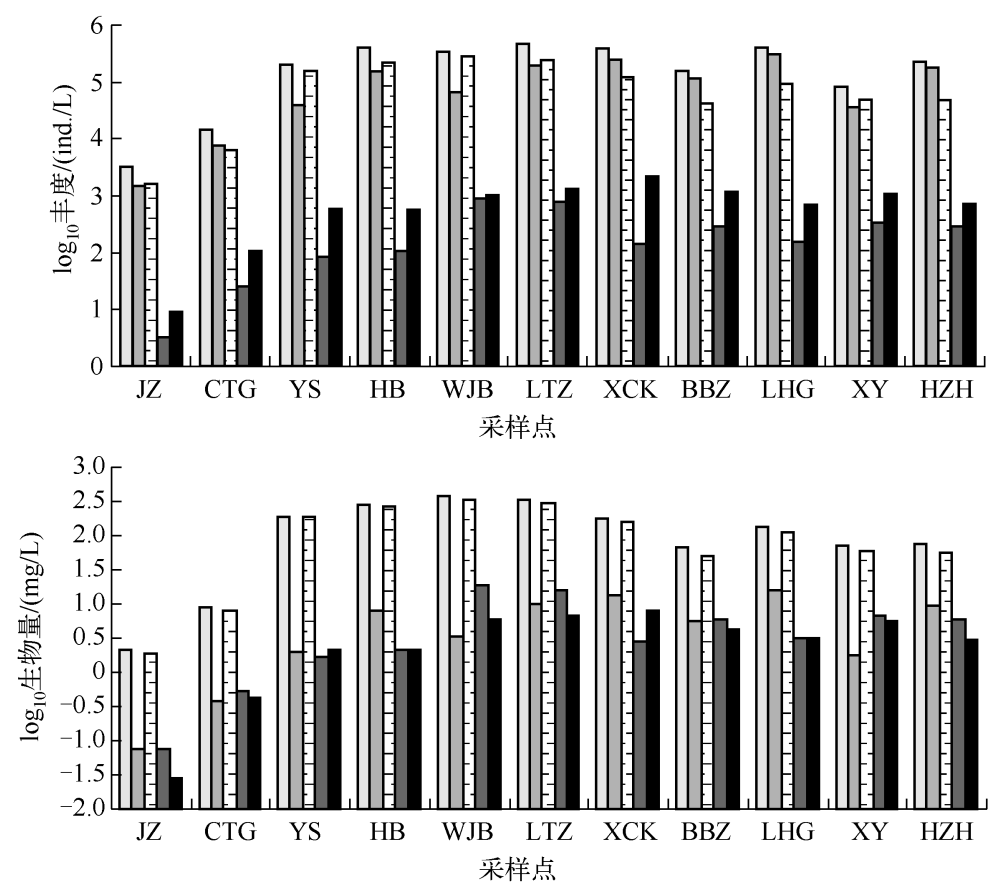

图 3 淮河干流不同采样点浮游动物及各类群的丰度和生物量

Fig. 3 Abundance and biomass of zooplankton and its taxas in different sites in the mainstream of Huaihe River

\section{4 浮游动物优势种}

以优势度 $>0.02$ 为标准 ${ }^{[18]}$, 桐柏金庄优势种最多, 为 16 种, 特别是喜净水的有壳类砂壳虫种类较多, 其次为长台关大桥、尹山、新城口、洪泽湖人口. 总体上, 淮河干流浮游动物上游优势种物种数高于中、下游. 不同采样点浮游动物优势种有交叉, 江苏似铃壳虫和针簇多肢轮虫为 10 个采样点的共有优势种, 螺形龟甲 轮虫和曲腿龟甲轮虫为 9 个采样点的共有优势种, 累枝虫、王氏似铃壳虫为 8 个采样点的共有优势种 (表3).

\section{5 浮游动物多样性指数和均匀度指数}

桐柏金庄、长台关大桥和尹山样点浮游动物 $H^{\prime}$ 值均大于 $3, J$ 值均大于 0.5 , 其他各采样点 $H^{\prime}$ 值为 $0.9 \sim$ $3.0, J$ 值为 $0.28 \sim 0.50$. 依据 $H^{\prime}$ 值为 $0 \sim 1.0$ 和 $J$ 值为 $0 \sim 0.3$ 时水质为重污染, $H^{\prime}$ 值为 $1.0 \sim 3.0$ 和 $J$ 值为 
$0.3 \sim 0.5$ 时水质为中污染, $H^{\prime}$ 值大于 3 和 $J$ 值为 $0.5 \sim 0.8$ 时水质为轻污染或无污染 ${ }^{[12,19]}$, 桐柏金庄、长台 关大桥和尹山水质为轻污染或无污染, 而其他各采样点水质均为中污染或重污染. 总体而言, 淮河干流上游 浮游动物 $H^{\prime}$ 和 $J$ 值均高于中、下游, 上游水质优于中、下游 ( 图 4).

表 3 淮河干流各采样点浮游动物优势种及优势度

Tab. 3 Dominant species and the dominance of zooplankton in different sites in the mainstream of Huaihe River

\begin{tabular}{|c|c|c|c|c|c|c|c|c|c|c|c|}
\hline 优势物种 & $\mathrm{JZ}$ & CTG & YS & $\mathrm{HB}$ & WJB & LTZ & XCK & BBZ & LHG & $\mathrm{XY}$ & $\mathrm{HZH}$ \\
\hline 具角角甲藻 Ceratium cornutum & - & 0.031 & - & 0.044 & - & 0.054 & 0.025 & 0.059 & - & - & - \\
\hline 角甲藻 Ceratium hirundinella & - & - & 0.023 & - & - & 0.024 & 0.072 & - & 0.039 & - & - \\
\hline 雉囊藻 Dinobryon sp. & - & - & - & - & - & - & - & - & - & 0.044 & - \\
\hline 空球藻 Eudorina elegans & - & - & - & - & 0.032 & - & - & - & 0.082 & 0.032 & 0.037 \\
\hline 裸藻 Euglena sp. & - & - & - & 0.101 & - & - & - & - & - & - & - \\
\hline 实球藻 Pandorina morum & - & - & - & - & - & - & - & - & - & 0.030 & - \\
\hline 扁裸藻 Phacus sp. & - & - & - & - & 0.137 & 0.034 & 0.080 & 0.065 & 0.038 & - & - \\
\hline 普通表壳虫 Arcella vulgaris & 0.022 & - & - & - & - & - & - & - & - & - & - \\
\hline 针棘匣壳虫 Centropyxis aculeata & 0.050 & 0.021 & - & - & - & - & - & - & - & - & - \\
\hline 橡子砂壳虫 Difflugia glans & 0.037 & 0.020 & - & - & - & - & - & - & - & - & - \\
\hline 球形砂壳虫 Difflugia globulosa & 0.044 & - & - & - & - & - & - & - & - & - & - \\
\hline 叉口砂壳虫 Difflugia gramen & 0.043 & - & - & - & - & - & - & - & - & - & - \\
\hline 砂壳虫 Difflugia sp. & 0.054 & - & - & - & - & - & - & - & - & - & - \\
\hline 瓶砂壳虫 Difflugia urceolata & - & - & 0.021 & - & - & - & - & - & - & - & - \\
\hline 累枝虫 Epistylis sp. & - & - & 0.021 & - & 0.031 & 0.094 & 0.074 & 0.237 & 0.313 & 0.241 & 0.044 \\
\hline 雉形似铃壳虫 Tintinnopsis conicus & - & - & 0.023 & 0.025 & - & - & 0.076 & - & 0.026 & - & 0.076 \\
\hline 江苏似铃壳虫 Tintinnopsis kiangsuensis & - & 0.155 & 0.138 & 0.101 & 0.087 & 0.045 & 0.135 & 0.163 & 0.074 & 0.185 & 0.152 \\
\hline 王氏似铃壳虫 Tintinnopsis wangi & - & 0.016 & - & 0.036 & 0.151 & 0.185 & 0.163 & 0.201 & 0.180 & - & 0.124 \\
\hline 钟虫 Vorticella sp. & 0.038 & 0.025 & - & - & - & - & - & - & - & 0.066 & 0.048 \\
\hline 晶囊轮虫 Asplachna sp. & - & - & - & - & - & - & 0.019 & - & & - & 0.090 \\
\hline 角突臂尾轮虫 Brachionus angularis & 0.028 & 0.028 & 0.024 & 0.061 & 0.024 & - & - & - & - & - & 0.042 \\
\hline 萝花臂尾轮虫 Brachionus calyciflorus & - & & 0.061 & - & - & - & - & - & - & - & - \\
\hline 钩状狭甲轮虫 Colurella uncinata & 0.054 & - & - & - & - & - & - & - & - & - & - \\
\hline 狭甲轮虫 Colurella sp. & 0.024 & - & - & - & - & - & - & - & - & - & - \\
\hline 叉角聚花轮虫 Conochilus dossuarius & - & - & - & - & - & - & 0.030 & - & - & - & 0.060 \\
\hline 长三肢轮虫 Filinia longiseta & - & 0.035 & 0.047 & 0.040 & - & - & - & - & - & - & - \\
\hline 奇异六腕轮虫 Hexarthra mira & - & - & 0.037 & - & - & - & - & - & - & - & - \\
\hline 螺形龟甲轮虫 Keratella cochlearis & - & 0.036 & 0.105 & 0.083 & 0.046 & 0.070 & 0.039 & 0.039 & - & 0.085 & 0.042 \\
\hline 矩形龟甲轮虫 Kerateua quadrata & - & - & - & - & - & 0.025 & - & - & - & 0.025 & - \\
\hline 曲腿龟甲轮虫 KeratelIa valaa & 0.027 & 0.081 & 0.051 & 0.052 & 0.174 & 0.087 & 0.025 & 0.042 & - & - & 0.050 \\
\hline 月形腔轮虫 Lecane luna & 0.025 & - & - & - & - & - & - & - & - & - & - \\
\hline 盘状鞍甲轮虫 Lepadella patella & 0.057 & - & - & - & - & - & - & - & - & - & - \\
\hline 爪趾单趾轮虫 Monostyla unguitata & 0.031 & - & - & - & - & - & - & - & - & - & - \\
\hline 钝齿单趾轮虫 Monostyla crenata & 0.028 & - & - & - & - & - & - & - & - & - & - \\
\hline 唇形叶轮虫 Notholca labis & - & 0.051 & - & - & - & - & - & - & - & - & - \\
\hline 针簇多肢轮虫 Polyarthra trigla & - & 0.120 & 0.267 & 0.227 & 0.133 & 0.186 & 0.094 & 0.119 & 0.094 & 0.149 & 0.085 \\
\hline 梳状疮毛轮虫 Synchaeta pectindta & - & 0.025 & - & 0.061 & 0.054 & - & - & - & - & 0.078 & - \\
\hline 等刺异尾轮虫 Trichocerca similis & 0.028 & - & - & - & - & - & - & - & - & - & - \\
\hline
\end{tabular}

\section{6 浮游动物群落结构与环境因子的关系}

利用 CANOCO 4.5 先进行 DCA 分析以检验其第 1 轴的梯度长, 其结果为 2.38 , 因此选择 RDA 分析进 行约束性排序. 通过前选法 (forward selection) 和蒙特卡罗检验 (Monte Carlo permutation test) 排除贡献小的因 
子, 最后得出水温 (WT)、溶解氧 ( DO) 和流速 (Velocity) 为影响淮河干流浮游动物分布的环境 因子 $(P<0.05)$ (图 5 ). 前 3 轴的累计值占特征 值总和的 $79.3 \%$, 表明这 3 轴集中了约 $4 / 5$ 的环 境因子对浮游动物分布格局影响的信息 (表 4). 3 种因子对 RDA 各轴的贡献存在显著差异, 其中 水温与第 1 轴呈正相关 $(r=0.83)$, 溶解氧与第 2 轴呈正相关 $(r=0.79)$, 流速与第 2 轴呈负相关 $(r=-0.46)$,与第 3 轴呈正相关 $(r=0.62)$ (表 $4)$. RDA 分析表明与浮游动物群落结构相关性 较强的环境因子在各季节是不同的,春季和冬季 浮游动物的丰度与水温呈负相关; 夏季浮游动物 丰度与水温和溶解氧呈正相关, 与流速呈负相 关; 秋季浮游动物丰度与水温和流速呈正相关 (图 5).

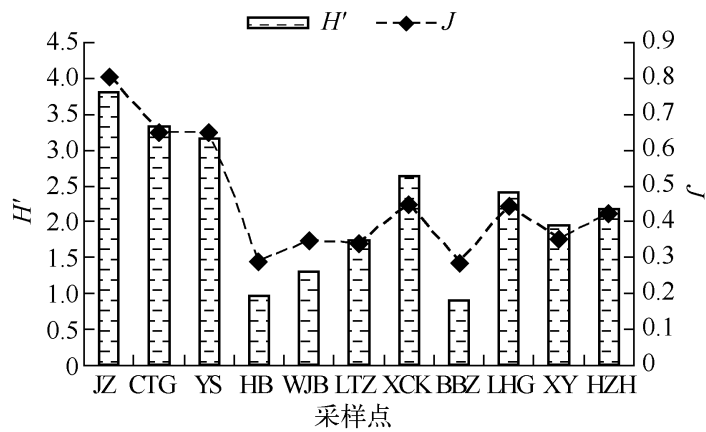

图 4 淮河干流不同采样点浮游动物 多样性指数和均匀度指数

Fig. 4 Shannon-Wiener index and Pielou evenness index of zooplankton in different sites in the mainstream of Huaihe River

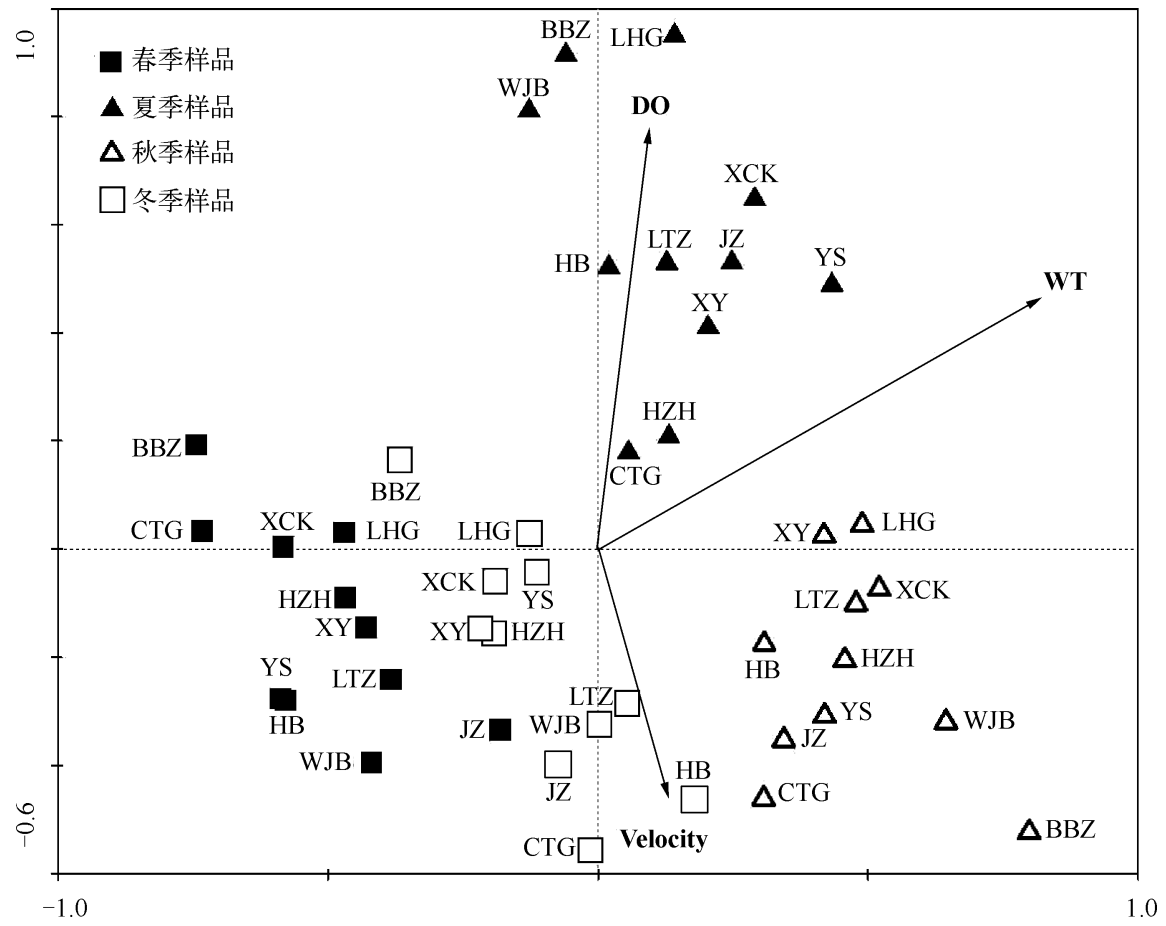

图 5 物种一环境相互关系的 RDA 排序图

Fig. 5 RDA of the species-environment relationships

\section{3 讨论}

淮河流域是典型的生态过渡带和脆弱性区域,生态类型复杂多样, 具有重要的经济价值、生态价值和社 会价值. 由于受自然因素和人类不合理活动的干扰,淮河流域生态脆弱性特征显著,生态系统退化和水土流 失都较为严重,加之淮河流域水资源紧缺,湖泊干涸和水体污染加剧了生态系统的脆弱性. 本次调查中, 淮 河干流浮游动物绝大多数为普生性种类, 轮虫种类数最多, 这与国内很多已知河流浮游动物群落结构相 
表 4 RDA 分析结果

Tab. 4 Summary results of RDA

\begin{tabular}{|c|c|c|c|c|}
\hline & & 轴 1 & 轴 2 & 轴 3 \\
\hline \multicolumn{2}{|l|}{ 水温 $/{ }^{\circ} \mathrm{C}$} & 0.83 & 0.47 & 0.17 \\
\hline \multicolumn{2}{|l|}{ 溶解氧/( mg/L) } & 0.10 & 0.79 & 0.47 \\
\hline \multicolumn{2}{|l|}{ 流速/( cm/s) } & 0.13 & -0.46 & 0.62 \\
\hline \multicolumn{2}{|l|}{ 特征值 } & 0.18 & 0.09 & 0.06 \\
\hline \multicolumn{2}{|l|}{ 属种一环境相关性 } & 0.89 & 0.87 & 0.80 \\
\hline \multirow[t]{2}{*}{ 累计方差百分比 } & 属种数据 & $17.6 \%$ & $27.0 \%$ & $32.5 \%$ \\
\hline & 属种一环境关系 & $43.0 \%$ & $65.9 \%$ & $79.3 \%$ \\
\hline
\end{tabular}

似 ${ }^{[20-21]}$. 浮游动物总丰度大小主要取决于轮 虫和原生动物丰度, 并且轮虫的生物量是淮 河干流浮游动物生物量的主体, 这与对国内 其他河流的研究结果一致 ${ }^{[20]}$, 说明河流浮游 动物组成的特异性. 由于轮虫具有独特的孤 雌生殖方式, 能在很短的时间内达到很高的 丰度,并且很快适应河流中理化环境的改变 和水文条件的波动, 因此, 在河流生境中浮游 动物通常以轮虫群落为主 ${ }^{[22-23]}$.

河流上、中、下游由多种异质性很强的生 态因子描述的生境形成了极为丰富的流域生 境多样化条件, 对生物群落的性质、优势种和

种群丰度产生了重大影响 ${ }^{[24]}$. 浮游动物游动能力弱, 因此流速较快的水域浮游动物种类数要低于流速较慢 的水域 ${ }^{[21]}$. 淮河上游河段短, 落差很大, 约 $178 \mathrm{~m}$, 水流速度快, 而中、下游河段较上游河段长, 而落差只有 6 16 m 左右, 水流速度缓慢 ${ }^{[25]}$, 因此理论上淮河上游采样点浮游动物种类数应低于中、下游采样点的种类 数, 然而本研究中从淮河干流上游至下游, 浮游动物物种数呈现逐渐减少的趋势. 浮游动物个体较小, 具有 较短的世代交替周期, 对环境敏感的种类难以生存, 因此, 随着水体富营养化程度提高, 浮游动物群落结构 趋于简单, 种类变少, 丰度增加, 多样性指数下降, 群落的稳定性降低 ${ }^{[26-27]}$. 一般而言, 大多数河流上游生物 多样性指数较高, 中、下游多样性降低 ${ }^{[20]}$. 淮河干流各采样点浮游动物群落结构的差异反映了各采样点水体 的水质状态. 相较淮河干流中、下游, 上游浮游动物物种数较多, 而浮游动物及各类群密度及生物量较低, 并 且上游浮游动物 $H^{\prime}$ 和 $J$ 值均高于中、下游, 说明淮河干流上游浮游动物群落结构稳定性大于中、下游, 上游 水质优于中、下游. 淮河中、下游流域的工业经济增长仍然走的是粗放型、高污染的老路, 生活污水和城市面 源污染已成为淮河中、下游污染的主要来源, 并且中、下游水流速度低于上游, 水体自净速度较缓慢, 富营养 化程度较高. 李京虎 ${ }^{[28]}$ 指出采砂作业引发的水质混浊、透明度降低等一系列负面影响导致水体自净能力降 低, 水质出现恶化迹象. 在水环境现场调查中, 淮河中、下游采样点中特别是淮滨、王家坝、鲁台子和蚌埠闸 下采砂场分布密集, 采砂船作业干扰严重, 浮游动物 $H^{\prime}$ 和 $J$ 值较低. 已有报道指出随着富营养化程度的增 加, 轮虫的食物更为丰富, 来源更为多样, 轮虫的丰度与水体的营养盐浓度呈正比 ${ }^{[29]}$. 淮河干流有采砂作业 的中、下游采样点轮虫丰度、生物量及水体营养程度均高于无采砂作业的上游采样点, 采砂船排放的生活垃 圾和油渍影响了淮河干流水质.

优势种种类数及其丰度对群落结构的稳定性有重要作用, 优势种种类越多且优势度越小, 则群落结构 越复杂、稳定. 本研究中, 淮河干流轮虫优势种为曲腿龟甲轮虫、螺形龟甲轮虫、针簇多肢轮虫, 甲壳动物优 势种为僧帽溞、象鼻溞、近邻剑水蚤、台湾温剑水蚤、汤匙华哲水蚤, 这与国内其他学者的研究结果相似 ${ }^{[6-7]}$. 原生动物优势种以角甲藻属、有壳类肉足虫和似铃壳虫属为主, 这与淮河含砂量较高有关. 砂壳虫、匣壳虫、 似铃壳虫、独角聚花轮虫、异尾轮虫主要出现在贫营养水体中, 是贫营养水体的指示生物; 而臂尾轮虫、龟甲 轮虫、多肢轮虫、长三肢轮虫主要出现在富营养水体, 是水体富营养化的重要指示生物 ${ }^{[00-31]}$. 洪松等 ${ }^{[20]}$ 指出 大多数河流上游为喜净水、急流的种类, 如有壳类砂壳虫等. 本研究中处于淮河上游的桐柏金庄、长台关大 桥、尹山优势种种类多, 群落结构复杂、稳定, 喜净水体的有壳类肉足虫、似铃壳虫、角甲藻种类较多, 优势度 较高, 而耐污性种类优势度较低; 淮河中、下游采样点优势种种类数较少, 群落结构稳定性较差, 耐污性种类 如累枝虫、针簇多肢轮虫、龟甲轮虫较多, 优势度较高. 淮河干流浮游动物的 $J$ 值处于中等偏低水平, 这与物 种数分布不均匀密切相关. 在 11 个采样点中, 其优势种类主要为累枝虫、江苏似铃壳虫、王氏似铃壳虫、曲 腿龟甲轮虫、螺形龟甲轮虫、针簇多肢轮虫等少数种类, 多数种类的分布频次明显偏低, 这必将导致其 $J$ 值 的降低.

赵长森等 ${ }^{[9]}$ 于 2006 年 4 月对淮河流域典型闸坝进行水生态调查指出, 大部分断面原生动物和轮虫丰度 所占比例很大, 与本研究结果一致; 其研究还指出蚌埠闸为中度和轻度污染, 临淮岗为轻污染或塞污染, 淮 
河干流水生态环境质量的突变点在临淮岗, 其上游水生态环境质量较好, 下游水生态环境质量有所降低. 本 研究中淮河干流上游水质为轻污染或无污染, 中、下游水质为中污染或重污染, 与 2011 年《安徽省水资源公 报》 ${ }^{[32]}$ 所得出的淮河流域水质处于中一富营养化程度的结论相一致, 特别是蚌埠闸为重污染, 临淮关为中污 染, 说明淮河流域水质进一步恶化.

大量研究表明,水温和溶解氧是影响浮游动物分布的重要环境因素 ${ }^{[33-36]}$. 本研究中,RDA 分析结果表明 水温与夏季和秋季浮游动物群落结构的相关性较强, 夏季浮游动物的分布与溶解氧浓度呈正相关. 浮游动 物随波逐流的生活方式使其更适宜生长在静止的水体, 流速较大的水体不是浮游动物的理想栖息处 ${ }^{[21]}$. 本 研究表明, 与其他 3 个季节相比, 夏季浮游动物丰度最高, 而流速最低, 夏季浮游动物群落结构与流速呈负 相关.

致谢: 感谢淮北师范大学生命科学学院的邓道贵教授和丁建华副教授提供本研究的理化数据, 并感谢安徽 大学资源与环境学院的周立志教授、周忠泽教授、赵秀霞、刘刚、刘雪花、罗子君、韩飞园、周非、吴可浩、郑猛 对本研究野外采集工作的大力协助.

\section{4 参考文献}

[1 1 ] 杨宇峰,黄祥飞. 浮游动物生态学研究进展. 湖泊科学, 2000,12(1):81-89. DOI 10.18307/2000.0113.

[2] 刘歆璞,王丽卿, 张 宁等. 青草沙水库后生浮游动物群落结构及其与环境因子的关系. 水生态学杂志, 2013,32 (5) :1238-1248.

[ 3 ] 吴 利, 冯伟松, 张堂林等. 湖北省西凉湖浮游动物群落周年动态变化及其与环境因子的关系. 湖泊科学, 2011,23 (4) :619-625. DOI 10. 18307/2011.0419.

[4] 丁建华,周立志, 邓道贵. 淮河干流软体动物群落结构及其与环境因子的关系. 水生生物学报, 2013,37 (2): 367-375.

[ 5] 邓道贵,许忠浩. 淮河蚌埠段水域浮游甲壳动物的初步研究. 淮北煤炭师范学院学报, 2006,27 (1):40-43.

[ 6 ] 邓道贵,杨 威,孟小丽等. 淮河中游浮游甲壳动物群落结构的季节动态. 水生生物学报, 2013,37(5):869-875.

[ 7 ] 都 雪, 王齐东, 张超文等. 洪泽湖轮虫群落结构及其与环境因子的关系. 湖泊科学, 2014,26(2):269-276. DOI 10. $18307 / 2014.0214$.

[ 8 ] 孙 璞,韩小勇.淮河流域水生生态系统现状分析.治淮,2013,(1):38-39.

[ 9 ] 赵长森,夏 军,王纲胜等. 淮河流域水生态环境现状评价与分析. 环境工程学报,2008,2(12):1698-1704.

[10] Patterson DJ, Hedley S. Free-living freshwater protozoa, a colour guide. London: Wolfe Publishing, 1992.

[11］蒋隻治,堵南山. 中国动物志・节肢动物门 ·甲壳纲・淡水枝角类. 北京:科学出版社, 1979.

[12］沈皿芬,章宗涉,龚循矩等. 微型生物监测新技术. 北京: 中国建筑工业出版社,1990.

[13] 王家楫. 中国淡水轮虫志. 北京:科学出版社, 1961 .

[14] 中国科学院动物研究所甲壳动物研究组. 中国动物志 - 节肢动物门 - 甲壳纲 - 淡水桡足类. 北京: 科学出版 社,1979.

[15］章宗涉,黄祥飞. 淡水浮游生物研究方法. 北京: 科学出版社, 1991 .

[16] Shannon CE, Weaver W. The mathematical theory of communication. Urbana, IL: University of Illinois Press, 1949.

[17] Pielou E. Species-diversity and pattern-diversity in the study of ecological succession. Journal of Theoretical Biology, 1966, 10: 370-383

［18］纪焕红, 叶属峰,刘 星. 南麇列岛海洋自然保护区浮游动物的物种组成及其多样性. 生物多样性, 2006,14 (3): $206-215$.

[19］刘 超. 上海市西南城郊结合地区河道的浮游动物组成及水质评价 [ 学位论文]. 上海:华东师范大学, 2008 .

[20］洪 松,陈静生. 中国河流水生生物群落结构特征探讨. 水生生物学报,2002,26(3) :295-305.

[21］吴 利,冯伟松,陈小娟等. 新疆伊犁地区夏季浮游动物群落结构特征. 应用生态学报, 2008,19(1): 163-172.

[22] Holst H, Zimmermann H, Kausch H et al. Temporal and spatial dynamics of planktonic rotifers in the estuary during spring. Estuarine, Coastal and Shelf Science, 1998, 47: 261-273.

[23] 周淑婵. 香溪河水系浮游动物生态学研究 [学位论文].武汉:中国科学院水生生物研究所, 2007.

[24] 董哲仁. 河流形态多样性与生物群落多样性. 水利学报,2003, (11):1-6.

[25] 唐元海. 淮河志第二卷・淮河综述志. 北京:科学出版社, 2000. 
[26] 吴 利, 冯伟松, 陈小娟等. 中山市淡水浮游动物区系调查. 动物学杂志, 2007,42(4): 135-143.

[27] 胡春英. 不同湖泊演替过程中浮游动物数量及多样性的研究. 水生生物学报, 1999,23(3):217-226.

[28］李京虎. 采砂对盘石水库水生态环境的影响.工程管理,2012,11:22-23.

[29] 王 庆, 杨宇峰. 珠江广州河段轮虫群落结构的初步研究. 水生生物学报, 2007,31(2) :233-239.

[30］许宝红, 肖调义, 金红春等. 利用浮游动物评价不同类型养殖水体营养状况. 淡水渔业,2011,41(1):10-15.

[31] 蒋志学,邓士谨. 环境生物学. 北京: 中国环境科学出版社, 1989.

[32] 安徽省水利厅. 安徽省水资源公报,2011:22.

[33] 陈光荣, 钟 萍, 张修峰等. 惠州西湖浮游动物及其与水质的关系. 湖泊科学, 2008, 20 (3):351-356. DOI 10 . 18307/2008.0314.

[34] 杨丽丽, 何光喜, 胡忠军等. 鲢鳙占优势的千岛湖浮游动物群落结构特征及其与环境因子的相关性. 水产学报, 2013,37 (6):894-903.

[35] 杜明敏,刘镇盛, 王春生等. 中国近海浮游动物群落结构及季节变化. 生态学报,2013,33(17):5407-5418.

[36] 杜明勇, 于 洋, 阳 振等. 太湖流域 2012 年枯水期浮游生物群落结构特征. 湖泊科学, 2014,26(5):724-734. DOI 10. $18307 / 2014.0510$. 